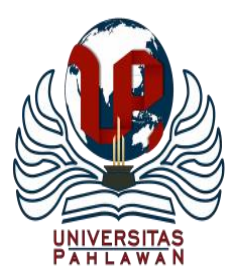

Jurnal Abdidas Volume 2 Nomor 1 Tahun 2021 Halaman 75-80

JURNAL ABDIDAS

http://abdidas.org/index.php/abdidas

\title{
Pendampingan Konsep Bisnis dalam Penerapan Manajemen Produk Home Industry di Nagori Bandar Masilam Kabupaten Simalungun
}

\author{
Rakhmawati Purba ${ }^{1 凶}$, Sri Winda Hardiyanti Damanik ${ }^{2}$ \\ STIE Bina Karya Tebing Tinggi, Indonesia ${ }^{1,2}$ \\ E-mail : rakhma.purba@gmail.com ${ }^{1} \underline{\text { sriwindahardiyantid@gmail.com }}^{2}$
}

\begin{abstract}
Abstrak
Peran wanita selaku ibu rumah tangga sangat penting dalam mensejahterakan keluarganya di samping mengurus rumah tangga, suami dan mendidik anak, juga membantu menambah penghasilan keluarga agar perekonomian keluarga stabil. Saat ini, dikarenakan kemajuan dan tuntutan zaman, peran wanita sangat dibutuhkan sebagai pendamping suami dalam mencari atau menambah nafkah keluarga. Umumnya dalam suatu keluarga suami dan istri bekerja untuk memenuhi kebutuhan anggota keluarga. Pengabdian ini bertujuan untuk wawasan dan pengetahuan para ibu rumah tangga dalam menambah pendapatan keluarga dengan mengembangkan usaha kecil dan memberikan motivasi dalam mengembangkan usaha rumahan (home industry) baik dari segi manajemen dan pemasaran dalam menghadapi persaingan bisnis. Teknik yang dipakai dalam melaksanakan pengabdian kepada masyarakat adalah sistem ceramah, memaparkan materi berupa teori-teori kewirausahaan, manajemen usaha dan manajemen pemasaran disertai memberikan contoh-contoh dan tanya jawab dengan peserta. Bagi kaum ibu yang sudah menjalankan usaha rumahan dimotivasi untuk mengembangkan pemasarannya dengan mengajarkan bisnis mengikuti kemajuan zaman di era revolusi industri 4.0, mengenalkan konsepkonsep pemasaran online atau lebih dikenal dengan digital marketing. Hasil yang diperoleh dapat menumbuhkan minat berwirausaha dikalangan ibu-ibu rumah tangga untuk menopang perekonomian keluarganya dan lebih meluaskan pemasaran hasil home industry yang selama ini masih memakai sistem offline atau tradisional, lebih luas lagi jangkauan pasarnya dengan memakai sistem online. Hal ini diharapkan dapat membuka lapangan kerja di Nagori Bandar Tinggi dengan memanfaatkan hasil alam yang ada disana.
\end{abstract}

Kata kunci: konsep bisnis, pemasaran, home industry

\section{Abstract}

The role of women as housewives is very important in the welfare of their families in addition to taking care of the household, husbands and educating children, as well as helping to increase family income so that the family economy is stable. Nowadays, due to the progress and demands of the times, the role of women is very much needed as a companion to their husbands in finding or increasing family income. Generally, in a family, husband and wife work to meet the needs of family members. This service aims to provide insight and knowledge for housewives in increasing family income by developing small businesses and providing motivation in developing home industries, both in terms of management and marketing in facing business competition. The technique used in carrying out community service is the lecture system, presenting material in the form of entrepreneurial theories, business management and marketing management accompanied by providing examples and questions and answers with participants. For mothers who are already running a home-based business, they are motivated to develop their marketing by teaching businesses to keep up with the times in the era of the industrial revolution 4.0, introducing the concepts of online marketing or better known as digital marketing. The results obtained can foster interest in entrepreneurship among housewives to support their family's economy and further expand the marketing of home industry products that have been using the off line or traditional system so far, the market reach is wider using the online system. It is hoped that this can open employment opportunities in Nagori Bandar Tinggi by utilizing the natural products that are there.

Keywords: business concepts, marketing, home industry

Copyright (c) 2021 Rakhmawati Purba, Sri Winda Hardiyanti Damanik

$\triangle$ Corresponding author

Address : STIE Bina Karya Tebing Tinggi

Email : rakhma.purba@gmail.com

DOI $\quad:$ https://doi.org/10.31004/abdidas.v2i1.215

ISSN 2721- 9224 (Media Cetak)

ISSN 2721- 9216 (Media Online) 


\section{PENDAHULUAN}

Home industry merupakan bentuk perusahaan kecil milik masyarakat secara perorangan. Keberadaannya sangat berperan dalam memberdayakan masyarakat agar memiliki kemandirian dalam bidang ekonomi (Emiliasari et al., 2020). Perkembangan usaha kecil di Indonesia merupakan salah satu prioritas dalam membangun ekonomi nasional. Hal ini dikarenakan usaha tersebut merupakan tulang punggung sistem ekonomi kerakyatan yang tidak hanya ditujukan untuk mengurangi masalah kesenjangan antar golongan pendapatan dan antar pelaku usaha, lebih dari itu pengembangannya mampu memperluas basis ekonomi dan dapat memberikan kontribusi yang siknifikan dalam mempercepat perubahan struktural, yakni meningkatnya perekonomian dan ketahan ekonomi nasional (Zuhri, 2013).

Pemasaran merupakan faktor penting dalam siklus yang berhubungan dengan pemenuhan kebutuhan konsumen. Dalam perusahaan, pemasaran merupakan salah satu dari kegiatan pokok yang dilakukan perusahaan untuk mempertahankan kelangsungan hidupnya, berkembang dan mendapatkan laba. Kegiatan pemasaran dalam perusahaan juga harus dapat memberikan kepuasaan pada konsumen, jika menginginkan usahanya tetap berjalan (Lukitaningsih, 2014).

Digital marketing pada dasarnya merujuk pada kegiatan promosi dan pencarian pasar melalui media digital secara online (Purwana et al., 2017). Dalam digital marketing penggunaan media sosial menjadi salah satu rujukan. Menurut (Wardhana, 2015), efek yang ditimbulkan oleh media sosial juga dirasakan sangat kuat karena melalui media massa informasi produk yang dipasarkan dapat lebih cepat menyebar dari satu pengguna ke pengguna media sosial lainnya. Media sosial juga memiliki keunggulan dalam penggunaan sarana untuk meriset pasar dan kompetitor. Media sosial sebenarnya membuka peluang yang cukup besar bagi dunia usaha dan model pemasaran baru yang lebih efektif. Sifatnya yang memudahkan interaksi antar penggunanya juga memungkinkan terbentuknya komunikasi pasar yang lebih efektif dan memiliki sifat transfaran, dimana pelanggan atau calon pembeli dapat melihat dan berinteraksi langsung melalui dunia maya menciptakan pasar yang sehat. (Wardhana, 2015) menyatakan bahwa strategi digital marketing berpengaruh hingga $78 \%$ terhadap keunggulan bersaing UMKM dalam memasarkan produknya.

Keluarga mempunyai peran penting dalam meningkatkan kesejahteraan sosial. Peran yang lebih dominan adalah peran seorang ibu untuk mengurus rumah tangga dan membantu suami dalam menambah pendapatan keluarganya. Potensi yang paling menarik untuk dikaji adalah potensi ibu rumah tangga ketika tidak hanya berperan sebagai ibu rumah tangga melainkan bekerja untuk membantu meningkatkan kesejahteraan keluarga (Marlina Telaumbanua, 2018). Peran wanita dalam meningkatkan kesejahteraan keluarga berperan aktif untuk mendukung ekonomi keluarga dalam mengelola keuangan rumah tangganya. Wanita harus mampu mensejahteraan rumah tangganya. Peran dan tanggung jawab wanita dalam membentuk keluarga sejahtera, sesungguhnya tidak dapat dipisahkan dari peran dan tanggung 
jawab seorang bapak. Keduanya saling melengkapi dan saling mendukung.

Nagori Bandar Masilam adalah sebuah desa dimana sebagian besar penduduknya bekerja sebagai buruh/pekerja pada perkebunan milik pribadi dan ada juga yang memiliki tanah untuk bercocok tanam. Umumnya kaum ibu rumah tangga membantu peran suami dalam mendukung kesejahteraan keluarga dengan membuka usahausaha kecil yang bisa dilakukan di rumah sembari mengurus keluarga, seperti berjualan makanan, membuat panganan dari hasil alam yang ada di Nagori tersebut seperti pisang, umbi-umbian dan buah-buahan.

Adapun tujuan pengabdian kepada masyarakat ini adalah:

1. Untuk menambah wawasan dan pengetahuan para ibu rumah tangga dalam menambah pendapatan keluarga dengan mengembangkan usaha kecil di rumah tangga.

2. Memotivasi dalam pengembangan home industry baik dari segi manajemen dan pemasaran dalam menghadapi persaingan bisnis.

\section{METODE}

Melalui program kegiatan pengabdian kepada masyarakat ini dan berdasarkan analisis kebutuhan yang telah dilaksanakan melalui observasi di lapangan, tim pengabdian memberikan solusi terhadap permasalahan yang dihadapi ibu-ibu yaitu melalui kegiatan pelatihan konsep bisnis. Dimana kegiatan ini oleh tim pelaksana pengabdian dilakukan melalui dua tahap.
Tahap yang pertama untuk memberikan pengenalan tentang home industry baik fungsi dan maafaat dari home industri sehingga dapat menangkap peluang pasar dan menyusun konsep bisnis. Kegiatan ini merupakan motivasi wirausaha / bisnis dalam bentuk sharing pengalaman dengan motivator untuk meningkatkan gairah wirausaha / bisnis dikalangan ibu-ibu. Kegiatan ini diarahkan untuk membangun daya pikir wirausaha bagi ibuibu sehingga dapat menumbuhkan motivasi wirausaha dan pengembangan usahanya.

Tahapan kegiatan yang kedua adalah pembuatan konsep bisnis merupakan bagian penting dari upaya pengembangan bisnis. Pelatihan dan pendampingan pembuatan konsep bisnis yang difokuskan untuk memberikan wawasan pengembangan bisnis serta dapat menghasilkan konsep bisnis bagi bisnis ibu-ibu yang akan dikembangkan. Dalam kegiatan ini peserta tidak hanya mendapatkan materi secara teori tetapi juga akan melakukan praktik langsung dimana setelah pemaparan materi oleh tim pengabdian, peserta pelatihan yang berjumlah sebanyak 30 orang dibagi menjadi 6 kelompok sesuai dengan bidang usaha yang sama untuk praktek dalam membuat konsep bisnis (business plan) dan masing masing kelompok mempersentasikan konsep bisnis (business plan) tersebut untuk dilakukan perbaikan atau koreksi secara bersama sama.

\section{HASIL DAN PEMBAHASAN}

Kegiatan pengabdian kepada masyarakat merupakan bagian dari Tridharma Perguruan Tinggi selain melaksanakan pengajaran dan 
penelitian. Setiap dosen dituntut untuk melakukan pengabdian minimal 1 (satu) x dalam 1 semester. Jadi dalam 1 tahun ajaran wajib melaksanakan 2 (dua) $\mathrm{x}$ pengabdian kepada masyarakat sesuai dengan bidang ilmu yang diemban. (LPPM STIE BINA KARYA, 2018).

Pengabdian kepada masyarakat yang dilakukan dosen STIE Bina Karya adalah usaha untuk membaktikan ilmu yang dimiliki sesuai bidangnya berupa teori dan mempraktekkannya di masyarakat, dalam hal ini memotivasi dan membangkitkan jiwa kewirausahaan ibu-ibu rumah tangga yang berperan untuk membantu perekonomian keluarga dengan membuka usahausaha bisnis kecil-kecilan di rumah yang bisa dikerjakan sembari mengurus rumah tangganya dan mendidik anak-anaknya di Nagori Bandar Tinggi Kecamatan Bandar Masilam, Kabupaten Simalungun.

Adapun sebagian dari para ibu tersebut sudah memiliki usaha sendiri tetapi pemasaran produksinya masih secara tradisional dan belum dikembangkan. Disini peran dosen sebagai pelaku pengabdian masyarakat sangat dibutuhkan dalam memberikan arahan (bimbingan dan masukan- masukan) dan pendampingan untuk kemajuan bisnis home industry yang sudah ada di Nagori Bandar Tinggi Tersebut. Adapun tahapan-tahapan kegiatan yang dilakukan dapat dilihat pada tabel 1 .

Pelaksanaan kegiatan pengabdian masyarakat ini dilakukan dengan metode ceramah, tutorial dan diskusi. Rencana sistematika pelaksanaan kegiatan pengabdian kepada masyarakat adalah sebagai berikut:

1. Metode ceramah kegiatan dengan memberikan penyuluhan materi ilmu tentang pasar dan strategi pemasaran secara umum, bauran pemasaran dan contoh-contoh aplikasi dunia pemasaran dalam bidang bisnis. Selanjutnya ilmu tentang pemahaman strategi pemasaran via digital marketing dan lingkup penerapannya dalam dunia bisnis. Kemudian transfer ilmu tentang pembuatan dan pengelolaan akun aplikasi Digital Marketing, seperti Facebook. Blog, Twitter, Instagram dan lain sebagainya. Alat bantu dalam penyampaian materi berupa infokus, laptop, power point materi, whiteboard dan instrument alat peraga seperti brosur, famplet dan lain sebagainya.

Tabel 1. Jadwal Pelaksanaan Kegiatan Pengabdian Kepada Masyarakat di Nagori Bandar Tinggi

\begin{tabular}{lll}
\hline No & Tgl & Uraian Kegiatan \\
\hline 1. & 4 Sept 2019 & $>$ Survey / cek lokasi \\
& & $>$ Pertemuan dengan panghulu nagori Bandar Tinggi dan perangkatnya \\
& & $>$ Permohonan izin dan diskusi soal lokasi serta sosialisasi program PKM yang akan dijalankan \\
\hline 2. & 9 Sept 2019 & Persiapan Pengabdian \\
& & - Brefing dan persiapan kegiatan \\
& & - Persiapan teknik Pengabdian \\
\hline 3. & 11 Sept 2019 & Pelaksanaan Pengabdian \\
& & - Pembukaan oleh Panghulu Nagori Bandar Tinggi \\
& & - Pemaparan materi tentang konsep bisnis dan home industri \\
& & - Pemaparan materi motivasi minat kewirausahaan \\
& & - Pemaparan materi pemasaran hasil kewirausahaan dengan memanfaatkan kemajuan teknologi \\
& & - Tanya jawab dan diskusi (penugasan Kelompok) \\
& & - Penutupan \\
\hline 4. & 12 Sept 2019 & Evaluasi Kegiatan \\
\hline
\end{tabular}


2. Metode tutorial. Kegiatan praktek tutorial pengenalan dan pemahaman pembuatan serta pemakaian aplikasi digital marketing dilakukan setelah pemberian materi-materi ceramah. Metode pelatihan dilakukan melalui pengajaran tatap muka dua arah antara tutor dan audiens dalam praktek langsung pembuatan dan pemakaian aplikasi digital marketing. Alat bantu berupa handphone dan laptop masingmasing peserta serta wifi atau paket internet yang tersedia dengan akses yang baik.

3. Metode diskusi dan tanya jawab. Metode ini dilakukan setelah pemberian materi selesai dilakukan dan penugasan kelompok. Peserta diberikan kesempatan untuk menyusun desain bisnis dan melakukan tanya jawab serta berdiskusi. Pada bagian diskusi ini baik peserta maupun tim pengabdian saling mendengar masukan dan pendapat terkait peningkatan kualitas produk dan pemasaran baik secara tradisional maupun yang akan diterapkan secara modern dengan online (digital marketing) (Leny Muniroh, Diah Yudhawati, 2017)

4. Evaluasi / tindak lanjut. Evaluasi proses dan hasil (pencapaian tujuan pelatihan) dilakukan dengan angket, tanya jawab dan observasi. Sedangkan evaluasi aspek penyelenggaraan pelatihan dilakukan dengan pemberian angket indikator keberhasilan dalam pelaksanaan pelatihan media pembelajaran dengan menggunakan aplikasi digital marketing, seperti Facebook, Blog dan Instagram.

Manfaat dari kegiatan pengabdian ini memberikan hasil efektif dan efisien dalam meningkatkan pendapatan kaum Ibu sebagai penopang ekonomi keluarga. Hal ini dapat dilihat dari tingkat antusias para ibu dalam mengikuti kegiatan dari awal sampai selesai dan interaksi dalam kelompok, tanya jawab yang spontan dan jujur. Namun terdapat kendala dalam pemahaman materi yang disampaikan dikarenakan tingkat pendidikan para ibu rumah tangga yang berbeda, dan perbedaan usia. Kendala lain yang ditemukan, tidak semua Ibu rumah tangga mampu melaksanakan peran gandanya sebagai seorang ibu dan istri serta pelaku wirausaha.

\section{SIMPULAN}

Kegiatan pengabdian masyarakat ini memberikan hasil:

1. Dosen-dosen Sekolah Tinggi Ilmu Ekonomi Bina Karya Tebing Tinggi mampu menjalankan Tridharma Perguruan Tinggi di bidang pengabdian kepada masyarakat dengan pengaplikasian ilmu yang dimiliki di bidang Manajemen, Kewirausahaan dan Pemasaran.

2. Menumbuhkan minat berwirausaha dikalangan wanita di Nagori Bandar Tinggi.

3. Kegiatan ini mampu menopang perekonomian keluarga sehingga kesejahteraan masyarakat dapat ditingkatkan.

\section{DAFTAR PUSTAKA}

Emiliasari, R. N., Kosmajadi, E., Inggris, P. B., Majalengka, U., Barat, J., Islam, M. P., Majalengka, P. U., \& Barat, J. (2020). Pendampingan Penerapan Manajemen Pemasaran. Jurnal PARAHITA ABDIMAS Jurnal Pengabdian Masyarakat, 1(2), 106115.

Leny Muniroh, Diah Yudhawati, H. (2017). PELATIHAN PEMASARAN SECARA 
80 Pendampingan Konsep Bisnis dalam Penerapan Manajemen Produk Home Industri di Nagori Bandar Masilam Kabupaten Simalungun - Rakhmawati Purba, Sri Winda Hardiyanti Damanik

DOI: https://doi.org/10.31004/abdidas.v2i1.215

ONLINE PADA UMKM TAS Abstrak.

LPPM STIE BINA KARYA. (2018). Panduan Pengabdian Masyarakat. LPPM STIE BINA KARYA.

Lukitaningsih, A. (2014). PERKEMBANGAN KONSEP PEMASARAN: IMPLEMENTASI DAN IMPLIKASINYA Ambar Lukitaningsih Fakultas Ekonomi Universitas Sarjanawiyata Tamansiswa Yogyakarta. 14(1).

Marlina Telaumbanua. (2018). Peran Ibu Rumah Tangga Dalam Meningkatkan Kesejahteraan Keluarga. Sosio Informa, 4(2), 418-436. https://doi.org/10.33007/inf.v4i2.1474

Purwana, D., Rahmi, R., \& Aditya, S. (2017). Pemanfaatan Digital Marketing Bagi Usaha Mikro, Kecil, Dan Menengah (UMKM) Di Kelurahan Malaka Sari, Duren Sawit. Jurnal Pemberdayaan Masyarakat Madani (JPMM), 1(1),1-17.

https://doi.org/10.21009/jpmm.001.1.01

Wardhana, A. (2015). Strategi Digital Marketing dan Implikasinya Pada Keunggulan Bersaing UMK di Indonesia. In Seminar Nasional Keuangan Dan Bisnis IV, April 2015, 327337.

Zuhri, S. (2013). Analisis Pengembangan Usaha Kecil dalam Rangka Pengentasan Kemiskinan. Jurnal Manajmen Dan Akutansi, 2(3). 